\title{
Russian-Belarus cooperation in the Arctic at the current stage
}

\author{
Daria Synchikova ${ }^{1}$, Regina Elizaveta Kudriavtceva ${ }^{2,}{ }^{*}$ and Javed Zafar $^{3}$ \\ ${ }^{1}$ Saint Petersburg State University, 199034, Saint Petersburg, Universitetskaya emb., 7-9, Russia \\ ${ }^{2}$ Junior researcher, Saint Petersburg State University, 199034, Saint Petersburg, Universitetskaya emb., 7-9, Russia \\ ${ }^{3}$ Doctor of Geo-political Science, Knowledge Architect at Centre For Study and Research, 110025, Hyderabad, D-317, Dawat Nagar, \\ Abul Fazal Enclave, Jamia Nagar, India
}

\begin{abstract}
Russia is one of the 8 member states of the Arctic Council, so the Arctic is one of the priority areas of Russia's foreign policy. Another player in the Arctic territories in cooperation with Russia is Belarus, which can provide assistance in many areas related to technological progress. In this article, the author examines which areas of cooperation between Russia and Belarus are the most successful, and what platforms (The Union State of Russia and Belarus or the EAEU) and institutions exist for this purpose. In addition, it is important to consider the problems that arise in the process of cooperation, as well as the question of whether a confrontation is possible within the integration association. The author also notes further lines of cooperation and opportunities for both states in the Arctic.
\end{abstract}

\section{Main interests of Russia and Belarus in the Arctic}

Nowadays the Arctic is one of the priority areas in the policy of the Russian Federation and other States that have a sphere of influence there. Russia's interests in this territory are quite obvious and are spelled out in the official strategy until 2035. According to it, the national interests of the Russian Federation in the Arctic consist primarily in ensuring the sovereignty of the state, mutually beneficial and stable partnership in international relations, and improving the level and quality of life of the population of the Arctic zone. In addition, its development for unhindered and safe extraction of minerals that contribute to increasing the country's economic and resource potential, expanding cooperation within the Northern route, which undoubtedly has a positive impact and makes Russian transport more competitive on the world market, as well as preserving the natural resources, flora and fauna of the Arctic territories, including indigenous peoples and their way of life [1].

Cooperation in the Arctic takes place mainly within the framework of the Arctic Council, which includes 8 Arctic countries (Canada, Russia, the United States of America, the Kingdom of Denmark, including Greenland and the Faroe Islands, Sweden, Norway, Finland and Iceland). Moreover, the author notes that despite the difference in resource potentials, the countries have quite similar goals, tasks and interests in the Arctic territories, which can be seen in their Arctic strategies and annual reports of the Council [2].

Unexpected news back in 2019 was the statement of the state Secretary of Belarus Grigory Rapota about the potential for cooperation with Russia in the Arctic region. He noted that despite the fact that the Republic of Belarus does not have its own sphere of influence, it has a large number of new technologies which can help to develop the Arctic under its harsh climatic conditions [3], especially low temperatures and ice storms, which make additional adjustments to the installation of floating stabilizing platforms for oil production.

Thus, the interests of Belarus extend to the sphere of infrastructure transformation, medicine, environmental and biodirvesity protection, as well as scientific and technological progress. Moreover, Belarus has an indirect interest in the Northern sea route. The main role here is assigned to the city of Gdansk, which has a large cargo terminal and serves not only Russia, but also Ukraine and Belarus, which do not have access to the Baltic sea [4].

Urbanization and the development of modern infrastructure in the Arctic region cause migration flows not only within Russia itself, but also from Belarus, because the Arctic, paradoxically, is the most urban part of Russia, where about $90 \%$ of the population lives in cities [5].

So, this Arctic cooperation can become a new round in relations between Russia and Belarus as the main allies on the world stage. In addition, it should be noted that Russian-Belarus cooperation really does not contradict the interests of both countries, but rather creates a solid basis for long-term and stable cooperation. In addition, Belarus has repeatedly stressed that its goal is to find those niches that will not run counter to the goals and objectives of Russia in this territory. The Foundation of this cooperation has always been such factors as common language, culture, history and, importantly, geographical proximity (the absence of

\footnotetext{
* Corresponding author: aethel@yandex.ru
} 
visa and customs borders), which makes it possible to simplify cooperation in the trade and economic sphere.

\section{Main platforms for cooperation: The Union State and the EAEU}

In the second chapter of the study, it is necessary to consider what sites are possible for Russian-Belarus cooperation on the Arctic territories. Firstly, the main and most logical base for interaction seems to be the Union State of Russia and Belarus, created in 1999 by President of the Russian Federation Boris Yeltsin and President of the Republic of Belarus Alexander Lukashenko. The Union State of Russia and Belarus has created the Arctic - SG Foundation, which considers issues of joint development of the Arctic region. The last event in the framework of the "Arctic-SG "was a meeting of representatives of the Fund, the company" Smartfood " and a delegation from Arkhangelsk, including representatives of the regional government [6]. This event was significant for the project to build a plant for the production of innovative food in Arkhangelsk. It is planned to install several high-tech lines for the production of eco-friendly semi-finished products based on Belarusian raw materials, which indicates the positive experience of cooperation between the Republic of Belarus and the Arkhangelsk region in particular.

Secondly, one of the most important goals of the Fund in accordance with the concept of the Union state program "Arctic-SG" is the development of innovative technologies and products for key industries in the conditions of gradually increasing environmental pressure [7]. Along with scientific and technological progress, it is important to take into account the development of human resources and socio-economic development, because only joint consideration of these industries can increase the efficiency of development of the Arctic territories.

The Fund "Arctic - SG" does not only create space for investment, but also contributes to a favorable image of the Arctic areas of Russia and Belarus, and also carrying out cultural policy in general. The Foundation cooperates with the Murmansk Arctic state University (MAGU), which is a base for Arctic research. It is worth noting that these studies will remain promising for a long time due to constantly changing natural conditions, global warming and its problems, which will allow talented young people to realize their potential.

The University also has a branch in Apatity, where it is planned to build an Arctic technology Park. A special place in Arctic research is occupied by the Kola research center, which consists of 11 institutes [8] connected by a horizontal management system, which only expands the opportunity for innovation and facilitates coordination of work. Returning to the list of students, specialists and young scientists, it should be noted that they have a unique opportunity to get an education and practice in the conditions of the region they are studying, and this certainly affects the quality of research and the development of innovative products.
Scientists of the Russian Academy of Sciences (RAS) and the national Academy of Sciences of Belarus have also joined forces and are successfully exchanging experience. For example, Russia, in our opinion, can borrow some knowledge about the distribution and concentration of intellectual resources, and the Republic of Belarus can adopt the experience of such organizations of the Russian Academy of Sciences as the Institute of problems of chemical physics, etc

The second important platform for interaction between Russia and Belarus is the Eurasian Economic Union (EAEU). It is obvious that despite the existence of cooperation with the countries of the Arctic Council, Russia is still interested in involving the EAEU partner States in implementing projects on its territory. The author focuses on the extraction of hydrocarbons in the Russian Arctic, since joint development of the Arctic shelf will strengthen the economic position of the entire integration Association and attract developing countries, such as Vietnam and Mongolia, to cooperate in the scientific and technical sphere. As a result, it should be noted that Russian-Belarusian cooperation cannot be viewed from one side, focusing only on Russia because of its Arctic status.

\section{Problems of cooperation. Is confrontation possible?}

However, there is an opinion that in order to develop and increase the level of cooperation within integration associations, there must be competition. If we consider the evolution of Arctic communities, it was entirely based on competition generated by harsh natural conditions. F. Fukuyama called this spontaneous socialization [9], when in order to adapt to the contrasting dynamics of daylight duration, sharp and frequent pressure drops and ultraviolet insufficiency, communities united to achieve the best result. In the author's opinion, the thesis "competition as the basis of cooperation for integration" in this case is fundamentally incorrect, despite the peculiarity of the Arctic spaces, which excludes a possible confrontation between Belarus and Russia in the future. In practice, it makes sense to create competition between large integration associations, for example, the EEU and the European Union in order to balance powers, but within the community everything should be aimed at improving the welfare of the association itself, its economic and trade prosperity. To do this, it is necessary to organize the structure of interaction between States, a hierarchy and a stable decision-making procedure.

Within the Union State, there are still problems in the adoption and implementation of programs due to the cumbersome bureaucracy. The procedure is delayed for a longer time than expected, and this fact requires special consideration and simplification of existing mechanisms [10]. 


\section{Conclusion}

Based on the information analyzed by the author, it can be concluded that the most convenient platforms for Russian-Belarusian cooperation are the Union State and the Eurasian Economic Union. Belarus' interests in the Arctic do not contradict Russia's, so a confrontation within the framework of cooperation or integration is impossible. Belarus offers assistance in the areas where the Russian Federation needs it, such as pharmaceuticals, medicine, scientific and technical transformation, and, of course, environmental monitoring. Within the framework of this cooperation, it is also necessary to pay attention to decision-making mechanisms in order to make this procedure more free and efficient. In any case, cooperation between the Russian Federation and Belarus in the Arctic is quite successful at the current stage and allows both countries to improve not only their international image in the Arctic region, but also to benefit the Eurasian economic community.

\section{References}

1. Decree of the President of the Russian Federation "on the fundamentals of state policy of the Russian Federation in the Arctic for the period up to 2035". Available online: http://static.kremlin.ru/media/events/files/ru/f8Zpjhp AaQ0WB1zjywN04OgKiI1mAvaM.pdf (2020)

2. D. Synchikova, R-E. A. Kudryavtseva, Policy of the Arctic Council in the sphere of environmental security, IOP Conf. Ser.: Earth Environ. Sci. 554, 012002 (2020). Available online: https://iopscience.iop.org/article/10.1088/17551315/554/1/012002 (2020)

3. Belarus invited Russia to cooperate in the Arctic// News.ru. 08.12.2019. Available online: https://news.ru/politics/belorussiya-predlozhilarossii-sotrudnichat-v-arktike/ (2020)

4. N. M. Antyushina, New Countries of the Arctic Council discover the Far North, Arctic and North 24, 80-95 (2016). Available online: https://vk.com/away.php?to=http $\% 3 \mathrm{~A} \% 2 \mathrm{~F} \% 2 \mathrm{Fww}$ w.arcticandnorth.ru\%2Fupload $\% 2$ Fiblock $\% 2 F d c 8 \%$ 2F06-_antyushina.pdf\&cc_key= (2020)

5. Arctic Human Development Report: Regional Processes and Global Linkages (Copenhagen, Nordisk Ministerrad, 2015)

6. "Arktika-SG" at the plant of innovative nutrition of LLC "Smartfood". Available online: https://arcticasg.ru/novosti/arktika-sg-na-zavodeinnovatsionnogo-pitaniya-ooo-smartfud/ (2020)

7. Arctic Vedomosti. Available online: https://www.arcticobserving.org/images/pdf/Arctic_ Herald/AH_03-2019_web.pdf (2020)

8. Rapota: the Union state will involve the youth of Belarus and Russia in the development of the Arctic. Available online: https://eurasia.expert/soyuznoe- gosudarstvo-podklyuchit-molodezh-k-osvoeniyuarktiki/ (2020)

9. F. Fukuyama, Trust. Social virtues and the path to prosperity (Moscow, AST, 2004)

10. S. M. Dedkov, Russian-Belarusian scientific cooperation at the first stage of Union relations: restoration of a common scientific space. Available online: https://cyberleninka.ru/article/n/rossiyskobelorusskoe-nauchnoe-sotrudnichestvo-na-pervometape-soyuznyh-otnosheniy-vosstanovlenie-edinogonauchnogo-prostranstva/viewer (2020) 